\title{
CARCASS CHARACTERISTICS AND MEAT QUALITY OF BARKI LAMBS FED RATIONS CONTAINING DRIED SUGAR BEET PULP WITH OR WITHOUT FIBROLYTIC ENZYMES
}

\author{
H.A.F. Rahmy, H.M. El Bana , G.M. Abdul Aziz and A. E. M. Mahmoud \\ Animal Production Research Department, Faculty of Agriculture, Cairo University, 12613, Giza, Egypt.
}

\section{SUMMARY}

\begin{abstract}
$\mathrm{T}$ wenty-five Barki lambs with an average body weight of $25 \pm 0.5 \mathrm{Kg}$, at 8 -months of age, were divided into 5-groups of 5-animals each, according to their live body weight in growth trial lasted for 90 days to study effect of replacing yellow corn by beet pulp in lambs diets with or without fibrolytic enzymes on carcass characteristics and meat quality. First group (G1) was fed the control ration, which consisted of concentrate feed mixture (CFM) and Alfalfa hay; second group (G2) was fed a ration where $50 \%$ of the corn was replaced with sugar beet pulp (SBP); third group (G3) was fed a ration where $75 \%$ of corn was replaced with SBP; fourth group (G4) was fed the same ration as G2 but supplemented with $4 \mathrm{~g} / \mathrm{head} / \mathrm{day}$ of fibrolytic enzymes and fifth group (G5) was fed the same ration as G3 but supplemented with $4 \mathrm{~g} / \mathrm{head} / \mathrm{day}$ of fibrolytic enzymes, like G4. Result showed that final slaughtered body weight (FSBW) was higher in G5 and G4 compared to other groups. However, the difference was significant $(\mathrm{P}<0.05)$ for G5 $(45.2 \mathrm{Kg})$ compared with the other groups. Significant main effects for enzyme supplementation, and SBP substitution at $50 \%$ and $75 \%$, were noted on FSBW. Dressing percentage was similar for all groups, but the amount of protein in meat was higher in animals fed rations without enzymes compared to the control group. Eye muscle (longesmus dorsi) was significantly different for G5 compared with the control group. The colour of meat was the same for all groups, but protein content in meat was significantly higher for G5 compared to the other groups. It may be concluded that SBP may substitute yellow corn at 50 and $75 \%$ in Barki lambs ration with enzyme positively effecting FSBW, as well as protein content in meat.
\end{abstract}

Keywords: lambs, beet pulp, enzyme, meat, carcass.

\section{INTRODUCTION}

One of the crucial aims in livestock feeding is to promote the use of local feeds and by-products in order to decrease feed cost (Guessous et al., 1989 and Lanza et al., 2001). Change in production system, aiming for increasing animal productivity and profitability is desirable, if meat quality and consumer acceptance is maintained (Arsenos et al., 2002 and Santos-silva et al., 2002). Nutritional factors have significant effects on the biochemical, structural and metabolic characteristics of muscles and on the dietetic value and sensory qualities of meat from ruminants (Geay et al., 2001). Changing traditional production systems may enhance the eating quality of sheep meat (Arsenos et al., 2002).

Sugar beet pulp (SBP) is a common by-product results from sugar industry and is widely used in animal nutrition as a source of energy (Fadel, 1999). Dried sugar beet pulp is characterized by high content of soluble fiber $19 \%$ (pectins, glucans), which is fermented primarily to acetate (Hall et al., 2000). Therefore, SBP is a candidate for partially substituting cereals in ruminant diets (Richardson et al., 2003; Norman et al., 2005).

Diets rich in wheat or barley decrease the firmness of subcutaneous adipose tissue owing to the high propionate concentration in the rumen. While dried beet pulp produces more acetate and less propionate in rumen and hence limits this problem. (Matray et al. 1994). The partial or total substitution of cereals by sugar beet pulp was investigated in several experiments with positive or negative effects (Normand et al., 1999 and Berthelot et al. 2001).

Exogenous fibrolytic enzymes have been used to improve the nutritive value of fiber-rich diets and subsequently the performance of cattle (El-wakeel et al., 2007) sheep (Cruywagan and Vanzyl, 2008) and goats (Stella et al., 2007).Meanwhile this can be achieved by direct feeding of these enzymes which increased DMI, passage rate and digestibility of DM, NDF and ADF (Stakes, 1992). Beauchemin et al. 
(2003) found that applying exogenous fibrolytic enzyme in ruminant rations improved feed digestibility. It had been shown that interaction between a pre-feeding enzyme and feed enhanced the beneficial effects of enzymes on ruminal fermentation (Giraldo et al., 2004). However, the addition of enzyme to diet immediately before feeding or direct addition of enzymes to ruminants has received considerably less attention.

Therefore, the aim of this study was to investigate the effect of partial substitution of yellow corn by dried sugar beet pulp at levels of 50 and $75 \%$ supplemented or not with oral fibrolytic enzymes on some Carcass parameters and chemical composition of meat in growing Barki lambs.

\section{MATERIALS AND METHODS}

\section{Animals, diets and enzyme}

Twenty-five growing male Barki lambs $(25 \pm 0.5 \mathrm{Kg}$ of BW) were used in this experiment. The animals were housed in groups (5 groups of 5 lambs each). The animals had continuous access to fresh water and vitamin-mineral block. The experiment lasted for 90 days. The animals were weighed biweekly to record the body weight and to calculate the average daily body gain and feed efficiency.

Ingredients and chemical composition of the diets are shown in (Table 1). The diets were formulated according to NRC (1985) guidelines. The diets were offered to the animals twice daily (9am and 4pm) to cover the total requirements according to NRC (1985). The experimental diets were formulated to test the effect of yellow corn grain substitution by dried sugar beet pulp (DSBP) (50 and $75 \%$ by weight) on performance of lambs. The control diet (G1) consisted of a concentrate feed mixture (70\%) along with alfalfa hay (30\%). The experimental diets G2, G3, G4, G5, contained the yellow corn in concentrate feed mixture substituted by DSBP at $50 \%$ with and without oral fibrolytic enzyme or substituted at $75 \%$ with and without oral fibrolytic enzyme respectively. Oarts were collected just before the next morning feeding. Alfalfa hay was the main source of roughage.

\section{Enzyme mixture}

An exogenous fibrolytic enzyme mixture, Miami, Fl 33145, recommended by AGRANCO CORP. (USA) was used to indicate its effects on performance of lambs. The mixture was orally given to each animal in G4 and G5 (4 g/d) just before second meal.

\section{Chemical analysis.}

Feeds were analyzed for proximate analyses according to (A.O.A.C., 1995) and nitrogen free extract was calculated by difference. Chemical composition of the experimental rations is shown in Table (1).

Table (1). Chemical composition of the ingredients, experimental concentrates feed mixture and ration (on DM basis).

\begin{tabular}{|c|c|c|c|c|c|c|c|}
\hline \multirow{2}{*}{ Item } & \multirow[b]{2}{*}{$\mathrm{DM}$} & \multicolumn{6}{|c|}{ Chemical composition \% (DM) } \\
\hline & & OM & $\mathrm{CP}$ & $\mathrm{CF}$ & $\mathrm{EE}$ & NFE & Ash \\
\hline \multicolumn{8}{|l|}{ Ingredients } \\
\hline Clover Hay & 90.76 & 88.68 & 16,80 & 19,42 & 4,25 & 48,21 & 11.32 \\
\hline Sugar beet pulp & 90.84 & 96.46 & 8.97 & 18.91 & 1.29 & 67.29 & 3.54 \\
\hline \multicolumn{8}{|l|}{ Experimental CFM } \\
\hline CFM, G2\&4 & 91.42 & 88.91 & 12.91 & 8.11 & 2.21 & 65.68 & 11.09 \\
\hline CFM, G3\&5 & 91.53 & 89.5 & 12.46 & 9.18 & 1.98 & 65.88 & 10.5 \\
\hline \multicolumn{8}{|l|}{ Experimental rations } \\
\hline G1-ration & 90.87 & 90.33 & 14.35 & 10.69 & 3.21 & 62.08 & 9.67 \\
\hline $\mathrm{G} 2 \& \mathrm{G} 4$ & 91.26 & 89.57 & 14.21 & 11.91 & 2.89 & 60.56 & 10.43 \\
\hline G3\&G5 & 91.13 & 89.76 & 13.88 & 12.59 & 2.73 & 60.56 & 10.24 \\
\hline
\end{tabular}




\section{Experimental procedures and sampling}

After 90 days of the experiment, three animals from each group were slaughtered in a slaughterhouse to measure the different carcass traits.

The lambs were slaughtered by exsanguination using conventional Islamic procedure after $16 \mathrm{~h}$ feed deprivation. Before slaughter, the live body weight was recorded. After complete bleeding, the animals were skinned and external organs (head, feet and skin) were weighed. Stripping, legging, dressing and evisceration were performed by adopting the standard procedures described by Gerrand (1964).The weight of hot carcasses and organs were recorded. The dressing percentage was obtained as percent of hot carcass weight to pre-slaughter weight.

Determination of chemical analysis of L. dorsi muscle (moisture, protein, fat and collagen) and physical characteristics were carried out in the Research Park, Faculty of Agriculture, Cairo University.

Meat chemical analysis was performed using Food Scan ${ }^{\mathrm{TM}}$ Pro meat analyzer (Foss Analytical A/S, Model 78810, Denmark).

According to the manufacturer's instructions about $50-100 \mathrm{gm}$ of raw meat (obtained from the 9th rib) were minced and put in the meat analyzer cup. The cup was inserted into the meat analyzer for scanning sample with infra-red to determine the chemical components.

Meat color was measured using Chroma meter (Konica Minolta, model CR 410, Japan) calibrated with a white plate and light trap supplied by the manufacturer. Color was expressed using the color instrumental parameters (CIE) L*, $\mathrm{a}^{*}$, and $\mathrm{b}^{*}$ color system (Yuksel et al. 2011). A total of three spectral readings were taken for each sample on different locations of the muscle. $\mathrm{L}^{*}$ (lightness) values measure (higher $\mathrm{L}^{*}$ value indicates a white color, while lower $\mathrm{L}^{*}$ value indicates a black color); $\mathrm{a}^{*}$ values measure redness (positive $\mathrm{a}^{*}$ value indicates a reddish color, while negative value measures greenish); and $b^{*}$ values measure yellowness (positive $b^{*}$ value indicates a more yellowish color, while negative value measures blueish). It is well known that higher values of lightness and positive one of redness and yellowness indicate that the meat is better than lower values of lightness and negative values of redness and yellowness (Honikel, 1998).

\section{Statistical analysis}

Collected data were subjected to statistical analysis using two way analysis SAS (1996) according to the following model: $Y_{i j}=\mu+B_{i}+E_{j}+B E_{i j}+E_{i j k}$; where: $\mu$ is the overall mean of $Y_{i j} ; B_{i}$ is the beet pulp level $i=$ 1 and $2 ; \mathrm{E}_{\mathrm{j}}$ is the enzyme level where $\mathrm{j}=1$ and $2 ; \mathrm{BE}_{\mathrm{ij}}$ is the interaction between beet pulp and enzyme level; $E_{\mathrm{ijk}}$ the experimental random error. The differences among means were separate according to Ducan's New Multiple Range test (Duncan's, 1955).

\section{RESULTS AND DISCUSSION}

\section{Effect of the experimental rations on carcass characteristics}

\section{Dressing percentage and eye muscle}

Carcass characteristics of the slaughtered lambs are given in Tables (2) and (3). Slaughter weights and hot carcass weights were slightly higher for lambs fed the 75\% SBP ration with Hydroenzime (G5). However, its dressing percentage was the lowest. There were no significant differences in the yields of edible offal's of lambs fed the different rations.

There are no significant differences were observed in the dressing percentages of all rations (Table 2). However, El-Badawi and El-Kady (2006) reported that the dressing percentage was much better for lambs fed 50\% SBP than those fed a commercial diet. McAllister et al. (2000) reported that enzyme supplementation, to concentrate rations, resulted in slight decrease in the dressing percentage than lambs fed concentrate rations without adding enzymes. The eye muscle weights are shown in Tables(2, 3). The G4 group (50 \% SBP with Hydroenzime) had the highest eye muscle weight $(200 \mathrm{~g})$. This weight was significantly higher than the control group (152.5) and G3 group (127.5 g). The weight of the bone of the eye muscle weight was significantly higher in G2 and G5 than the other groups. 
Table (2). Carcass characteristics of lambs fed the experimental rations.

\begin{tabular}{|c|c|c|c|c|c|c|c|}
\hline \multirow[t]{2}{*}{ Item } & \multicolumn{7}{|c|}{ Experimental ration group } \\
\hline & G1 & G2 & G3 & G4 & G5 & $\mathrm{P}$ value & $\mathrm{SE}$ \\
\hline Fastingbodyweight,kg & 42.5 & 42.3 & 41.9 & 46 & 46.9 & 0.088 & 9.41 \\
\hline After -slaughterweight, $\mathrm{kg}$ & 40.7 & 40.2 & 40.2 & 42.6 & 45.2 & 0.109 & 1.02 \\
\hline Hot carcassweight, $\mathrm{kg}$ & 20.8 & 20.9 & 20.6 & 21.7 & 22.6 & 0.134 & 4.15 \\
\hline Dressingpercentage, $\%$ & 48.9 & 49.4 & 49.16 & 49.13 & 48.18 & ------ & ----- \\
\hline \multicolumn{8}{|l|}{ Edibleoffalsweights, $g$} \\
\hline Liver & 665 & 610 & 627 & 595 & 585 & 0.210 & 1.818 \\
\hline Heart & 145 & 127 & 137 & 145 & 135 & 0.061 & 0.89 \\
\hline De-fattedkidneys & 105 & 105 & 105 & 100 & 120 & 0.306 & 1.558 \\
\hline Spleen & 55 & 52.5 & 55 & 45 & 47 & 0.102 & 0.22 \\
\hline \multicolumn{8}{|l|}{ Dissectedcarcasstraits } \\
\hline $\begin{array}{l}\text { Eye muscle weight,g (longesmus } \\
\text { dorsi) }\end{array}$ & $152.5^{\mathrm{bc}}$ & $170^{\mathrm{ab}}$ & $127.5^{\mathrm{c}}$ & $200^{\mathrm{a}}$ & $167.75^{\mathrm{ab}}$ & 0.019 & 0.83 \\
\hline Bone of eye muscle weight,g & $107.5^{\mathrm{b}}$ & $125^{\mathrm{a}}$ & $85^{\mathrm{c}}$ & $97^{\mathrm{b}}$ & $122.25^{\mathrm{a}}$ & 0.0001 & 0.37 \\
\hline
\end{tabular}

Table (3). Carcass characteristics of lambs due to main effect of sugar beet pulp and hydroenzime.

\begin{tabular}{|c|c|c|c|c|c|c|c|c|}
\hline \multirow{3}{*}{ Item } & \multicolumn{4}{|c|}{ SBP main effect } & \multicolumn{4}{|c|}{ Hydroenzime main effect } \\
\hline & SBP & SBP & $\mathrm{P}$ & SE & Without & With & $\mathrm{P}$ & SE \\
\hline & $50 \%$ & $75 \%$ & value & & & & value & \\
\hline Fasting body weight, $g$ & 44.13 & 44.4 & 0.860 & 1.28 & $42.1^{b}$ & $46.5^{\mathrm{a}}$ & 0.02 & 8.35 \\
\hline After-slaughter weight, $g$ & 41.4 & 42.7 & 0.388 & 1.16 & $40.2^{\mathrm{b}}$ & $43.9^{\mathrm{a}}$ & 0.038 & 8.79 \\
\hline Hot carcass weight, g & 21.3 & 21.6 & 0.553 & 3.86 & $20.7^{\mathrm{b}}$ & $22.2^{\mathrm{a}}$ & 0.026 & 3.02 \\
\hline Dressing percentage, $\%$ & 49.26 & 48.67 & & & 49.28 & 48.65 & & \\
\hline \multicolumn{9}{|l|}{ Edible offals, $\mathrm{g}$} \\
\hline Liver & 602.5 & 606.25 & 0.889 & 1.57 & 618.75 & 590 & 0.3101 & 1.355 \\
\hline Heart & 136.25 & 136.5 & 0.951 & 0.37 & 132.5 & 140.25 & 0.092 & 0.3912 \\
\hline De-fatted kidneys & 102.5 & 112.5 & 0.215 & 0.45 & 105 & 110 & 0.514 & 0.485 \\
\hline Spleen & 48.75 & 51 & 0.265 & 0.203 & $53.75^{\mathrm{a}}$ & $46^{\mathrm{b}}$ & 0.005 & 0.115 \\
\hline \multicolumn{9}{|l|}{ Dissected carcass traits } \\
\hline $\begin{array}{l}\text { Eye muscle (longesmus } \\
\text { dorsi) wt, } \mathrm{g}\end{array}$ & $185^{\mathrm{a}}$ & $147.625^{\mathrm{b}}$ & 0.0007 & 0.947 & $148.75^{\mathrm{b}}$ & $183.88^{\mathrm{a}}$ & 0.001 & 0.98 \\
\hline Bone of eye muscle, wt, $g$ & $111.25^{\mathrm{a}}$ & $103.63^{\mathrm{b}}$ & 0.021 & 0.747 & 105 & 109.88 & 0.094 & 0.750 \\
\hline
\end{tabular}

\section{Colour of meat}

One of the carcass characteristics is colour of the slaughtered lamb's meat. The meat colour parameters are presented in Table (4). No significant differences were observed among groups in lightness (L) and redness (a) of the meat. However, the group that received $75 \%$ SBP (G3) had significantly $(P \leq 0.05)$ more yellowish (b) meat than all other groups. In same context, Yuksel et al., (2011) where they reported nonsignificant differences in redness of meat among a control group and groups receiving 4 or $8 \%$ sugar beet pulp. They also stated that the yellowness of meat was significantly $(P<0.01)$ higher in sugar beet pulp than the control diet. 
Table (4). Colour of lambs meat fed on the experimental rations.

\begin{tabular}{llll}
\hline Item & Colour & & \\
\cline { 2 - 4 } & Lightness(L) & Redness(a) & Yellowness(b) \\
\hline SBP main effect & & & \\
$50 \%$ & 40.85 & 16.59 & $3.4850^{\mathrm{b}}$ \\
$75 \%$ & 42.22 & 16.79 & $4.7300^{\mathrm{a}}$ \\
$\mathrm{P}$ value & 0.3828 & 0.6304 & 0.0251 \\
SE & 1.0244 & 0.2706 & 0.2822 \\
Hydroenzime main effect & & & \\
Without & 42.67 & 16.71 & 4.55 \\
With & 40.41 & 16.67 & 3.67 \\
P value & 0.1703 & 0.9185 & 0.0809 \\
SE & 1.0453 & 0.2317 & 0.3505 \\
Interaction between SBP and Hydroenzime & & & \\
G1 & 41.41 & 15.94 & $3.22^{\mathrm{b}}$ \\
G2 & 43.00 & 16.42 & $3.685^{\mathrm{b}}$ \\
G3 & 42.34 & 17.01 & $5.41^{\mathrm{a}}$ \\
G4 & 38.71 & 16.78 & $3.285^{\mathrm{b}}$ \\
G5 & 42.11 & 16.57 & $4.05^{\mathrm{b}}$ \\
$\mathrm{P}$ value & 0.4172 & 0.2802 & 0.0159 \\
SE & 1.158 & 0.28809 & 0.2408 \\
\hline a,b, $\cdots$ means in the same column for each main effect or interaction followed by different superscripts are significantly \\
different (P<0.05). G1: control ration, G2: sugar beet pulp replacing 50\% of the corn, G3: sugar beet pulp replacing \\
$75 \%$ of the corn, G4: sugar beet pulp replacing 50\% of the corn plus Hydroenzime, G5: sugar beet pulp replacing $75 \%$ \\
of the corn plus Hydroenzime.
\end{tabular}

\section{Chemical composition of meat}

The chemical composition of the meat is presented in Table(5). The collagen level of the group fed $50 \%$ SBP (G2) was significantly higher than the other four groups. Also the groups fed $50 \%$ SBP had significantly higher collagen percentage than those fed $75 \%$ SBP. The groups fed Hydroenzime had significantly lower collagen than the groups that were not fed the Hydroenzime.

The fat percentage of the meat of the group fed $50 \%$ SBP (G2) was significantly higher than all other groups. Similar results were reported by El-Badawi and El-Kady (2006) when using $50 \%$ SBP. However, the groups fed $75 \%$ SBP had significantly lower fat level than those fed $50 \%$ SBP (Table 5).

The protein percentage of the meat of the group fed $75 \%$ SBP with Hydroenzime (G5) was significantly higher than the control group and G2 and G3 groups. This contradicts the results of Bodas et al., (2007) who reported no significant differences in the protein percentages among groups of lambs fed on different sugar beet pulp levels. No significant differences were observed between the groups fed Hydroenzime and the groups that were not fed Hydroenzime.

\section{CONCLUSION}

The different finishing diets used for Barki lambs had acceptable performance in terms of dressing percent, eye muscle, chemical and color of the meat. Supplying fibrolytic enzymes (Hydroenzime) to the rations improved lamb performance. It was concluded that the best results were obtained when 50 or $75 \%$ of the corn was substituted with dried sugar beet pulp and adding Hydroenzime $(4 \mathrm{gm} / \mathrm{h} / \mathrm{d})$. It may be recommended, for sheep producers, to add Hydroenzime to improve their animal performance significantly. 
Table (5). Chemical composition of lambs meat fed on the experimental rations.

\begin{tabular}{|c|c|c|c|}
\hline \multirow[t]{2}{*}{ Item } & \multicolumn{3}{|c|}{ Chemical composition \% } \\
\hline & Collagen & Fat & Protein \\
\hline \multicolumn{4}{|c|}{$\underline{\text { SBP main effect }}$} \\
\hline $50 \%$ & $1.37^{\mathrm{a}}$ & $5.93^{\mathrm{a}}$ & $20.95^{\mathrm{b}}$ \\
\hline $75 \%$ & $1.17^{\mathrm{b}}$ & $4.55^{\mathrm{b}}$ & $21.65^{\mathrm{a}}$ \\
\hline$P$ value & 0.0385 & 0.0393 & 0.0202 \\
\hline $\mathrm{SE}$ & 0.088 & 0.559 & 0.1359 \\
\hline \multicolumn{4}{|c|}{$\underline{\text { Hydroenzime main effect }}$} \\
\hline Without & $1.39^{\mathrm{a}}$ & 5.57 & 21.29 \\
\hline With & $1.14^{\mathrm{b}}$ & 4.91 & 21.3 \\
\hline $\mathrm{P}$ value & 0.0126 & 0.2562 & 0.9846 \\
\hline SE & 0.0717 & 0.595 & 0.2027 \\
\hline \multicolumn{4}{|c|}{ Interaction between SBP and Hydroenzime } \\
\hline $\mathrm{G} 1$ & $1.15^{\mathrm{b}}$ & $4.79^{b}$ & $20.67^{\mathrm{c}}$ \\
\hline G2 & $1.58^{\mathrm{a}}$ & $7.31^{\mathrm{a}}$ & $21.12^{\mathrm{bc}}$ \\
\hline G3 & $1.15^{\mathrm{b}}$ & $4.54^{\mathrm{b}}$ & $20.77^{\text {bc }}$ \\
\hline G4 & $1.22^{\mathrm{b}}$ & $3.83^{b}$ & $21.47^{\mathrm{ab}}$ \\
\hline G5 & $1.13^{\mathrm{b}}$ & $5.28^{b}$ & $21.83^{\mathrm{a}}$ \\
\hline$P$ value & 0.0065 & 0.014 & 0.0199 \\
\hline SE & 0.0725 & 0.4099 & 0.1507 \\
\hline
\end{tabular}

\section{REFERENCE}

A.O.A.C. (1995).Methods of Analysis. Vol. 1: Agriculture chemicals, Contaminants, Drugs. 16th ed. Association of official Analytical chemists, Washingon, D.D., USA. Animal Feed Science and Technology, 70, 23-39.

Arsenos, G.,G.Banos, P.Fortpmaris,N. Katsaounis, C. Stamataris and L.Tsaras, (2002). Eating quality of lambs meat: Effects of breed, sex, degree of maturity and nutritional managements. Meat sci., 60(4), 379387.

Beauchemin, K. A., D. Colombatto, D. P. Morgavi and W. Z. Yang (2003).Use of exogenous fibrolytic enzymes to improve feed utilization by ruminants. J. Anim. Sci. 81, 37-47.

Berthelot, V., J. Normand, P. Bas, and N. B. Kristensen (2001).Softness and fatty acid composition of subcutaneous adipose tissue, and methylmalonic acid concentrations in the plasma of intensively reared lambs. Small Ruminant Research, 41, 29-38.

Bodas ,R.; A.B.Rodriguez, S.Lopez, B.Fernandez, A.R. Mantecona and F.J.Giraldeza, (2007). Effects of the inclusion of sodium bicarbonate and sugar beet pulp in the concentrate for fattening lambs on acid-base status and meat characteristics. J. Anim. Sci., 77:696-702.

Cruywagen, C.W. and W.H. Vanzyl (2008).Effects of a fungal enzyme cocktail treatment of high and low forage diets on lamb growth. Anim. Feed Sci.Technol. 145, 151-158.

Duncan, D. B. (1955).Multiple Range and Multiple F test. Biometrcs, 11: 10.

El wakeel, E.A., E.C. Titgemeyer, B.J. Johnson, C.K. Armendariz, and J.E. Shirley (2007).Fibrolytic Enzymes to increase the nutritive value of dairy feedstuffs. J. Dairy Sci. 90, 5226-5236.

El-Badawi, A.Y. and R.I. El-Kady (2006).Effect of partial replacement of concentrates with sugar beet pulp on performance, carcass characteristics and energyutilization of growing sheep.Inter. J.oFAgric.\&Biol.,344-348. 
Fadel, J. G. (1999).Quantitative analyses of selected plant by-product feedstuffs, a global perspective. Anim. Feed Sci. Technol. 79:255-268.

Geay, Y.; D.Bauchart, J. F. Hocquette and J. Culioli (2001).Effect of nutritional factors on biochemical, structural and metabolic characteristics of muscles in ruminants, consequences on dietetic value and sensorial qualities of meat. Reproduction Nutrition Development, 41:(1),1-26

Gerrand, F. (1964).Meat Technology. $3^{\text {rd }}$ edition Leonard Hell Limited, London.

Giraldo, L. A.; M. J. Ranilla; M. L. Tejido and M. D. Carro (2004). Effects of cellulase application form on the invitro rumen fermentation of tropical forages. In J.Anim.Feed Sci., 13 (suppl.). p.63-66.

Guessous, F.; N.Rihani, A. Kabbali and L. Johnson (1989).Improving feeding system for sheep in a Mediterranean rain-fed cereals/ livestock area of Morocco.J. Anim. Sci.,67(11): 3080-3086.

Hall, M. B., J. P. Jennings, B. A. Lewis, and J. B. Robertson (2000). Evaluation of starch analysis methods of feed samples. J. Sci. Food Agric. 81:17-21.

Honikel, K. O.(1998). Reference methods for the assessment of physical characteristics of meat. Meat Sci., 49:447-457.

Lanza, M.,A.Priolo, L.Biondi, M. Bella and H. B. salem (2001). Replacement of cereal grains by orange pulp and carob pulp in faba bean-based diets fed to lambs: effects on growth performance and meat quality. Animal Rech., 50(1): 21-30.

Matray, M., L. Sagor and E. Van Quackebeke (1994).Influence de la composition du regime d' engraiementsur la qualite des carcasses d'agneaux. Renc.Rech.Ruminants.1-205.

McAllister, T.A.,K.Stanford, H.D.Bae,R.J.Treacher, A.N.Hristov, J.Baah, J.A.Shelford, and K.J. Cheng (2000).Effect of surfactant and exogenous enzyme on digestibility of feed and on growth performance and carcass traits of lambs. Can. J. Anim. Sci., 80:35-44.

Norman, J., P. Bas, B. Berthelot and D. Sauvant (2005). Relationship between fatty acid composition and softness score of adipose tissue in intensively reared lambs fed with concentrate based on cereals or on beet pulp. Anim. Res. 54:269-282.

Normand, J., M. Theriez, P. Bas, B. Ausousseau and D. Sauvant (1999).Effect of energy source, cereals vs sugar beet pulp, on growth performance and carcass quality of intensively reared lambs.Annales de Zootechnie, 48(5), 367-380.

NRC (1985).Nutrient requirements of domestic animals Nutrient requirements of sheep 5th Ed. National Academy of Sciences- National Research Council, Washinton D.C., USA.

Richardson, J. M., R. G. Wilkinson and L. A. Sinclair (2003).Synchrony of nutrient supply to the rumen and dietary energy source and their effects on the growth and metabolism of lambs. J. Anim. Sci. 81:13321347.

Santos, S. J.,R.J.B. Bessa and S. F. Santos (2002).Effect of genotype, feeding system and slaughter weight on the quality of light lambs II. Fatty acid composition of meat (research paper).Livestock production science, 77(2-3), 187-194.

SAS (1996). SAS users guide statistical analysis system inistitute, Inc., Cary, Nc, USA.

Stakes, M.R. (1992). Effect of an enzyme mixture, an inoculant and their interaction on silage fermentation and dairy production. J. Dairy Sci. 75: 764-773.

Stella, A.V., R. Paratte, L. Valnegri, G. Cigalino, G. Soncini, E. Chevaux, V. Dell'Orto, G. Savoini, (2007).Effect of administration of live Saccharomyces cerevisiae on milk production, milk composition, blood metabolites, and faecal flora in early lactating dairy goats.Small Rumin. Res. 67, 7-13.

Yuksel, S.,L.Turgut,M.Yanar,M.Aksu,G. Kaban and N. Unlu (2011).Fatty acid composition lean color and driploss of the different muscles from young HolsteinFriesian bulls finished on diet containing varied proportions of wet sugar beet pulp and wheat straw.Anim. Feed. Sci. Technol., 17(5):696-703. 

مواصفات الذبحية وجودة اللحم لحملان البرقى المغذاة علي علائق محتوية علي تفل بنجر السكر الجاف, مع أو

\author{
حسن عوني فؤاد رحمي و هشام عبد الجواد البناو جلال عبد العزيز و عادل عيد محم محمود \\ قسم الإنتاج الحيوانى، كلية الزراعة، جامعة القاهرة
}

استخدم عدد 25 حمل برقي بمنوسط وزن 26 كجم ومتوسط عمر 8 شهور، قسمت إلي خمس مجموعات (خمس حيو انات في كل

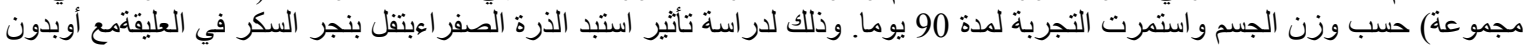

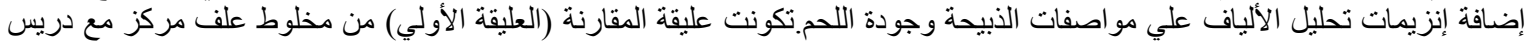

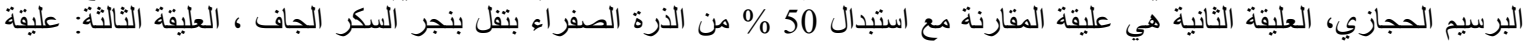

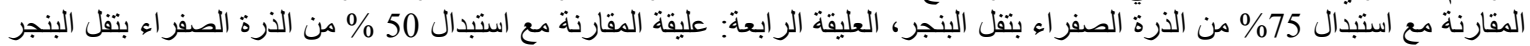

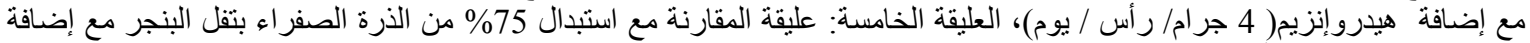
هيدرو إنزيم( 4جرام / رأس / يوم).

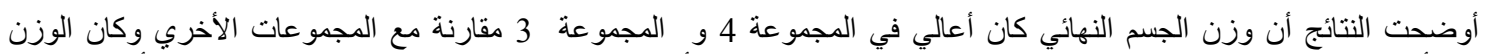

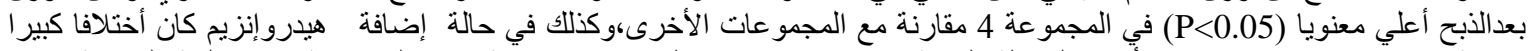

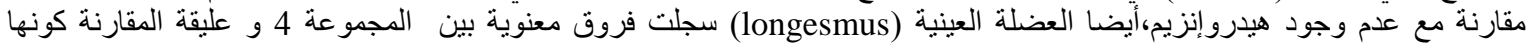

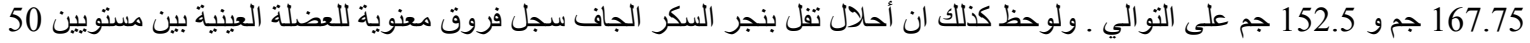

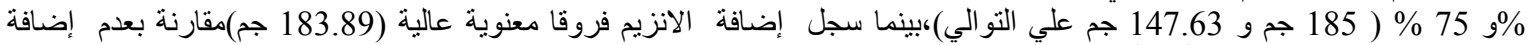

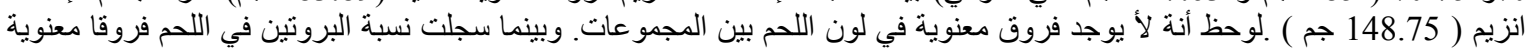
في المجمو عة 4 مقارنة بالمجمو عات الأخرى.

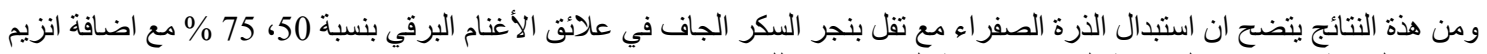
fibrolytic 